\title{
Cerebral and pulmonary involvement in an immunocompromised host
}

\author{
Lokesh Shahani
}

Department of Internal

Medicine, Baylor College of

Medicine, Houston, Texas, USA

\section{Correspondence to}

Dr Lokesh Shahani,

lokesh83@hotmail.com

Accepted 29 January 2015
CrossMark

\section{DESCRIPTION}

A 71-year-old man with newly diagnosed, untreated acute myeloid leukaemia presented with fever, cough and confusion. Complete blood count showed neutropenia $\left(90 \mathrm{cells} / \mathrm{mm}^{3}\right)$, lymphopenia (350 cells $/ \mathrm{mm}^{3}$ ) and $90 \%$ circulating blast. Initial chest X-ray showed evidence of new right lower lobe infiltrates, which were absent on a chest X-ray 3 weeks ago (figure 1). A CT scan brain revealed multiple enhancing lesions in temporal and occipital area. An MRI performed later, confirmed the same lesion with restricted diffusion (figure 2). With a presentation of pulmonary and cerebral involvement in an immunocompromised host the differential for this presentation was broad. Bacterial causes such as Nocardia and possibly streptococcal and staphylococcal infections were considered. Fungal causes especially Aspergillus, Fusarium and Mucorales were also high on the differential. Blood cultures and cultures from the bronchial alveolar lavage were obtained and the patient was started on linezolid, meropenem and liposomal amphotericin B; however the patient died within the first $24 \mathrm{~h}$. The initial staining of the bronchial alveolar lavage sample demonstrated hyphal elements and few days' later growth was identified on the fungal culture and the organism was identified as Rhizomucor pusillus, an agent of mucormycosis. Cerebral involvement with mucormycosis has been previously reported and is related

\section{3 weeks prior to admission}
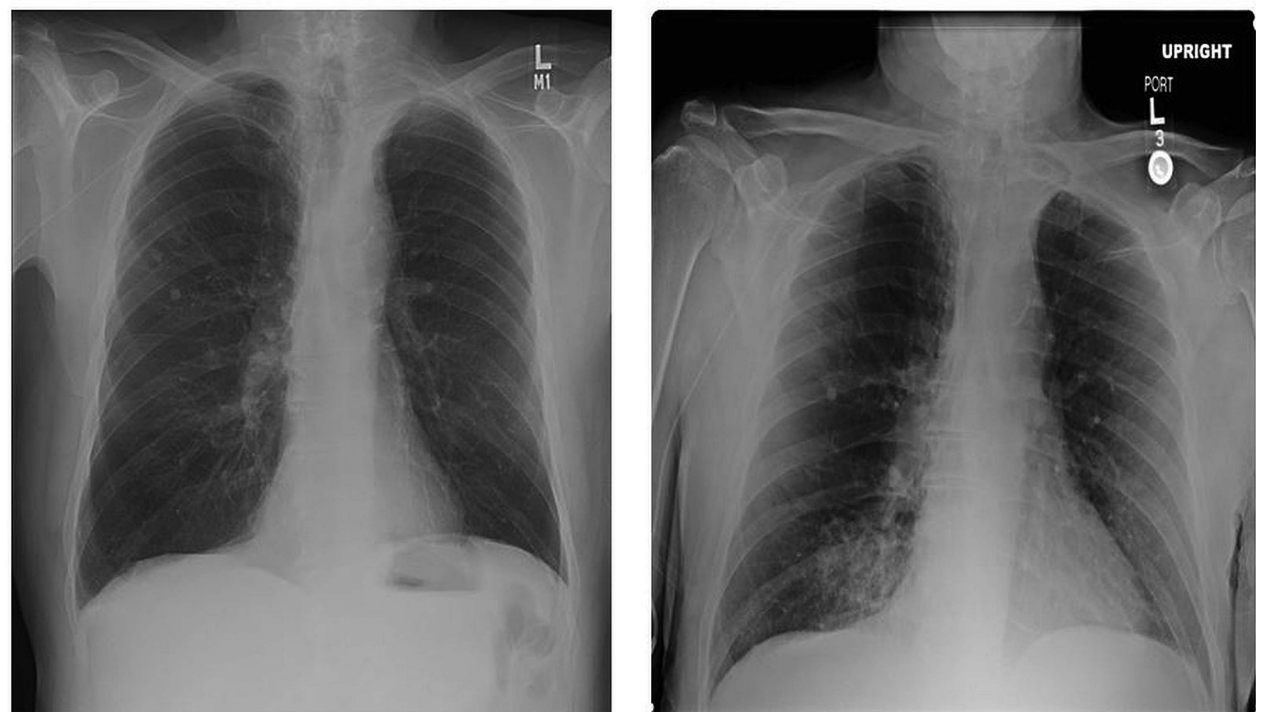

Figure 1 Chest X-ray demonstrating new right lower lobe infiltrates.

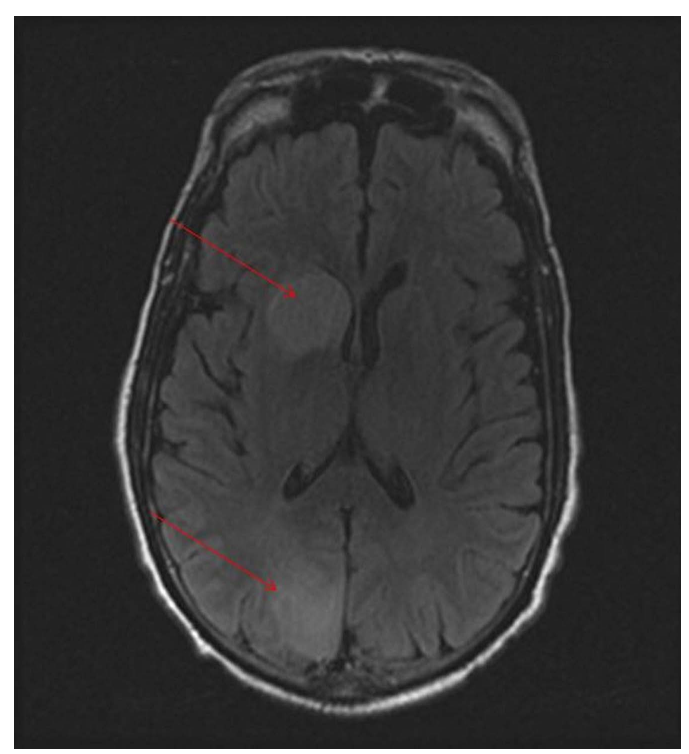

Figure 2 MRI brain demonstrating enhancing lesions in temporal and occipital area.

to contiguous infection or haematogenous dissemination from another organ, most likely lungs. ${ }^{1}$ This case highlights the importance of considering disseminated mucormycosis as a cause of pulmonary and cerebral involvement in patients with hematological malignancy. 


\section{Learning points}

- Mucormycosis are a group of filamentous fungii which are capable of forming severe life-threatening infections in immunocompromised patients.

- Central nervous systems involvement with mucormycosis is related to contiguous infection from the adjacent structures (eg, sinuses) or haematogenous dissemination from another organ, most likely lungs.

- Delayed intravenous amphotericin B-based therapy has been associated with an increase in mortality rate and is an independent predictor of poor outcome among patients with hematological malignancy and mucormycosis.
Competing interests None.

Patient consent Obtained.

Provenance and peer review Not commissioned; externally peer reviewed.

\section{REFERENCE}

1 Roden M, Zaoutis T, Buchanan W, et al. Epidemiology and outcome of zygomycosis: a report of 929 reported cases. Clin Infect Dis 2005;41:634-53.

Copyright 2015 BMJ Publishing Group. All rights reserved. For permission to reuse any of this content visit http://group.bmj.com/group/rights-licensing/permissions.

BMJ Case Report Fellows may re-use this article for personal use and teaching without any further permission.

Become a Fellow of BMJ Case Reports today and you can:

- Submit as many cases as you like

- Enjoy fast sympathetic peer review and rapid publication of accepted articles

- Access all the published articles

- Re-use any of the published material for personal use and teaching without further permission

For information on Institutional Fellowships contact consortiasales@bmjgroup.com

Visit casereports.bmj.com for more articles like this and to become a Fellow 